\title{
MULTIPLE STEROID HORMONE LEVELS IN DEPRESSED PATIENTS AND NORMAL CONTROLS BEFORE AND AFTER EXOGENOUS ACTH
}

\author{
Timothy L. GeHRis, ${ }^{1}$ ROger Kathol, ${ }^{1,2}$ William H. Meller, ${ }^{3}$ \\ JUAN F. LOPEZ, ${ }^{4}$ and RICHARD S. JAECKLE 5
}

Departments of ${ }^{1}$ Psychiatry and ${ }^{2}$ Internal Medicine, University of Iowa, College of Medicine, Iowa City, Iowa, ${ }^{3}$ Department of Psychiatry, University of Minnesota Hospitals and Clinics, Minneapolis, Minnesota, and ${ }^{4}$ Mental Health Research Institute; University of Michigan, Ann Arbor, Michigan, U.S.A.; ${ }^{5}$ Posthumous

(Received 27 August 1990; in final form 1 February 1991)

\section{SUMMARY}

Forty depressed patients and 36 age- and sex-matched controls were given $250 \mu \mathrm{g} \mathrm{ACTH}_{1-24}$ by IV bolus. Plasma steroid hormone levels were measured prior to and $60 \mathrm{~min}$ after ACTH administration. The depressed patients had significantly greater cortisol (F), 11-deoxycortisol (S), androstenedione $(\mathrm{AD})$, and $17 \alpha$-hydroxyprogesterone $(17 \alpha-\mathrm{OHP})$ responses (delta; $p<0.05)$ and a marginally greater $11 \beta$-hydroxyandrostenedione (11 $\beta$-OHAD) response (delta; $p=0.091$ ) than the controls. There was no significant difference in the corticosterone (B) response between the two groups.

With the exception of $11 \beta-O H A D$, all the steroid hormones were significantly negatively correlated with age in the controls, but only $S$ and $A D$ marginally demonstrated this relationship in the depressed patients. F, S, AD, $17 \alpha-\mathrm{OHP}$, and $\mathrm{B}$, but not $11 \beta-O H A D$, were significantly positively correlated with each other in the controls, but only F was significantly correlated with AD in the depressed patients. These data suggest that the hypercortisolemia found in some depressed patients involves increased precursor and metabolite levels both at baseline and in response to exogenous ACTH, compared to controls. Furthermore, variability in these precursors is greater in depressed patients, and their relationship to age is lost. These findings are consistent with the hypothesis that adrenal products other than cortisol also could be related to affective symptoms.

\section{INTRODUCTION}

REVIEW OF THE LITERATURE reveals a substantial amount of evidence of hypercortisolism in some populations of depressed patients (Stokes, 1987; Arana \& Mossman, 1988). While much of the research on hypercortisolemia in depressed patients has centered on the limbic and hypothalamic systems, few studies have investigated adrenal gland activity, despite the fact that reversal of corticosteroid production by adrenal resection or ablation in patients with Cushing's disease is an effective means of treating the high incidence of depression in this population (Kathol, 1985); i.e., there appears to be something in adrenal output that effects emotion.

Address correspondence and reprint requests to: Dr. Roger G. Kathol, Department of Psychiatry, University of Iowa, College of Medicine, 500 Newton Road, Iowa City IA 52242, USA. 
The adrenocorticotropin $(\mathrm{ACTH})$ stimulation test has been used to investigate peripheral abnormalities of the hypothalamo-pituitary-adrenal axis by assessing adrenal cortex responsiveness. Some investigators have reported a higher cortisol response to exogenous ACTH in actively depressed patients compared to normal controls (Amsterdam et al., 1983; 1986; Jaeckle et al., 1987) or to those who have recovered from their depression (Endo et al., 1974; Amsterdam et al., 1987a; Fang et al., 1988a). Others (Carpenter \& Bunney, 1971; Sclare \& Grant, 1972) have not observed this difference.

When using the ACTH stimulation test to study adrenal responsiveness in depressive illness, most investigators have concentrated only on the adrenal steroid, cortisol. The secretion of the cortisol precursors progesterone (Strott et al., 1969), 17 $\alpha$-hydroxyprogesterone (Strott et al., 1969), and 11-deoxycortisol (Liddle et al., 1962), as well as corticosterone (Peterson \& Pierce, 1960) its precursor, deoxycorticosterone (Crane \& Harris, 1966; Harris et al., 1967; Biglieri et al., 1969; ), and some adrenal androgens, dehydroepiandrosterone (Vaitukaitis et al., 1969), androstenedione (Rivarola et al., 1966) and 11 $\beta$-hydroxyandrostenedione (Lejeune-Lenain et al., 1980), also are stimulated by ACTH in man. These steroid hormones, however, have received little or no attention in assessments of adrenal responsiveness to endogenous or exogenous ACTH in depressed patients.

Since biologic activity is largely determined by the chemical structure and stereotaxis of steroid molecules, precursors and metabolites of cortisol could play a significant role in producing changes in CNS activity, i.e., in influencing the development of affective symptoms. It is known, for instance, that cortisol can adversely affect neuronal function (Sapolsky, 1985) and that the receptors which mediate glucocorticoid effects are sensitive to the structure of the compound (McEwen et al., 1986). Studies on rats have identified two distinct classes of corticosteroid receptors in the brain which resemble corticosteroid receptors found in the kidney (type I) and the liver (type II) (reviewed in McEwen et al., 1986; 1988; De Kloet et al., 1987; De Kloet \& Reul, 1987). The type I receptor is primarily localized in the hippocampus and has a high affinity for aldosterone and the major glucocorticoids (corticosterone in the rat and cortisol in other species) (McEwen et al., 1986; 1988; De Kloet et al., 1987; De Kloet \& Reul, 1987). The type II receptor has a lower affinity for glucocorticoids and does not bind mineralocorticoid steroids (McEwen et al., 1986; 1988; De Kloet et al., 1987; De Kloet \& Reul, 1987). This receptor is more widely distributed, occurring not only in the hippocampus but also in the lateral septum, central amygdala, supraoptic nucleus, paraventricular nucleus, and nucleus tractus solitarii (McEwen et al., 1986; 1988; De Kloet et al., 1987; De Kloet \& Reul, 1987). Because the type II receptors have lower glucocorticoid affinity it is thought that these receptors are only occupied during the corticosteroid stress response, while the type I receptors are occupied during the basal state (McEwen et al., 1986; 1988; De Kloet et al., 1987; De Kloet \& Reul, 1987). In turn, because of the widespread distribution of the type II receptors, the regulation of the CNS response to stress is, at least in part, likely affected by high levels of corticosteroids. It is possible that steroid compounds other than cortisol, even when produced in much smaller amounts, could be more closely related to the production of depressive symptoms than would be cortisol.

In this study we investigated the basal hormonal state and the responses of cortisol, 11deoxycortisol, corticosterone, $17 \alpha$-hydroxyprogesterone, androstenedione, and $11 \beta$-hydroxyandrostenedione to exogenous $\mathrm{ACTH}_{1-24}$ administration in patients with major depression and in normal controls. 


\section{SUBJECTS AND METHODS}

\section{Subjects}

Sixty-four patients were recruited from the inpatient psychiatric service at the University of Iowa Hospitals and Clinics (UIHC). The patients were screened by a research assistant with the National Institute of Mental Health's Diagnostic Interview Schedule (DIS) (Robins et al., 1981) $(n=39)$ or by clinical interview by a psychiatrist $(n=25)$, and all diagnoses were confirmed by consensus among the investigators. Of the 64 patients recruited, 50 met DSM-III (American Psychiatric Association, 1980) criteria for major depressive disorder (MDD). Ten of these 50 patients were excluded for the following reasons: one patient also met criteria for anti-social personality disorder, three were receiving carbmazepine, three were taking oral contraceptives, one was using hydrocortisone cream, one was receiving estrogen replacement, and one had recently received ECT. Therefore, 40 patients with MDD (13 male and 27 female) were studied before and after the administration of exogenous $\mathrm{ACTH}_{1-24}$. The mean age $( \pm \mathrm{SD}$ ) was $35.0 \pm 14.3 \mathrm{yr}$ (range $16-70 \mathrm{yr}$ ) (men: $32.9 \pm 14.1 \mathrm{yr}$, women: $36.0 \pm 14.6 \mathrm{yr}$ ). Only one patient was not receiving a psychotropic medication. The medications and doses were unchanged from admission and throughout the testing, to avoid the effects of drug withdrawal (Devanand et al., 1984; Dilsaver \& Greden, 1984; Krause et al., 1987). The 17-item Hamilton Rating Scale for Depression (HRSD) (Hamilton, 1960) and the Carroll Rating Scale for Depression (CRSD) (Carroll et al., 1981) were administered to 36 patients. All patients gave informed written consent prior to entering the study.

Thirty-six age- and sex-matched healthy control subjects were identified by advertisement or contacted from a list of research participants obtained from the Clinical Research Center at the UIHC. There were 15 men and 21 women; their average age was $35.8 \pm 12.6 \mathrm{yr}$ (range 21-62 yr) (men: $32.9 \pm 11.9 \mathrm{yr}$; women: $38.0 \pm 12.9 \mathrm{yr}$ ). All were free of psychiatric symptoms, were on no medications at the time of the study, and gave informed written consent. Twenty-eight completed an HRSD, and 32 completed a CRSD. All 36 control subjects were studied before and after administration of $\mathrm{ACTH}_{1-24}$.

\section{Procedures}

Each participant received $250 \mu \mathrm{g} \mathrm{ACTH}_{1-24}$ by IV bolus between $1300 \mathrm{~h}$ and $1700 \mathrm{~h}$ to take advantage of the relatively steady basal afternoon state. An IV butterfly catheter was routinely placed $30 \mathrm{~min}$ before testing began. Blood samples for steroid analysis were drawn before and $60 \mathrm{~min}$ after the administration of $\mathrm{ACTH}_{1-24}$ into chilled tubes containing EDTA. All specimens were centrifuged and the plasma removed and frozen at $-20^{\circ} \mathrm{C}$ within $1 \mathrm{hr}$ of collection. Some of the subjects (35 patients and 30 controls) also completed a dexamethasone suppression test (DST) by taking orally $1 \mathrm{mg}$ of dexamethasone at $2330 \mathrm{~h}$. The DST was performed at least $48 \mathrm{hr}$ after the ACTH test. Blood samples for post-DST cortisol levels were drawn at $0800 \mathrm{~h}$ and $1600 \mathrm{~h}$ the following day. DST nonsuppressors were identified as those with post-DST cortisol levels $>5 \mu \mathrm{g} / \mathrm{dl}$ at either $0800 \mathrm{~h}$ or $1600 \mathrm{~h}$.

\section{Hormone Assays}

Cortisol (F) was measured in duplicate unextracted plasma samples by a standard ${ }^{125}$ I double-antibody radioimmunoassay (RIA) developed at the Medical Research Facility at the UIHC as described previously (Jaeckle et al., 1987). Intra-assay coefficients of variation were $8.3 \%, 6.6 \%$ and $5.1 \%$, and interassay coefficients of variation were $14.6 \%, 13.4 \%$ and $16.7 \%$, for cortisol levels of $2.7 \mu \mathrm{g} / \mathrm{dl}, 11.7 \mu \mathrm{g} / \mathrm{dl}$ and $23.6 \mu \mathrm{g} / \mathrm{dl}$, respectively.

11-deoxycortisol (S), 17 $\alpha$-hydroxyprogesterone (17 $\alpha$-OHP), androstenedione (AD), and corticosterone (B) were measured by RIA kits purchased from ICN Biomedicals, Los Angeles, CA (formerly Radioassay Systems Laboratories, Carson, CA). 11 $\beta$-hydroxyandrostenedione (11 $\beta$-OHAD) was measured by RIA kits purchased from Inter Sci Diagrostics, Los Angeles, CA.

S and $17 \alpha-O H P$ levels were measured in duplicate unextracted plasma samples. Both assays used ${ }^{125} \mathrm{I}$ labelled steroids as the ligand and goat anti-rabbit $\gamma$-globulin to separate the bound from the unbound steroid. The $S$ intra-assay coefficients of variation were $7.4 \%$ and $3.3 \%$, and the interassay coefficients of variation were $4.1 \%$ and $14.1 \%$, for levels of $0.21 \mu \mathrm{g} / \mathrm{dl}$ and $2.41 \mu \mathrm{g} / \mathrm{dl}$, respectively. Cross-reactivity with $17 \alpha-\mathrm{OHP}$ was $3.9 \%$, deoxycorticosterone $0.22 \%$, progesterone $0.16 \%$, and cortisol $0.09 \%$. All other cross-reactivities were $<0.03 \%$. $17 \alpha$-OHP intra-assay coefficients of variation were $0.0 \%, 4.9 \%$ and $3.3 \%$, and interassay coefficients of variation were $18.2 \%, 11.2 \%$ and $8.9 \%$, for levels of $0.11 \mathrm{ng} / \mathrm{ml}, 0.73 \mathrm{ng} / \mathrm{ml}$ and $3.99 \mathrm{ng} / \mathrm{ml}$, 
respectively. The $17 \alpha$-OHP antiserum cross-reacted $0.58 \%$ with $17 \alpha$-hydroxypregnenolone, $0.18 \%$ with progesterone, $0.06 \%$ with deoxycorticosterone, and $1.48 \%$ with 11-deoxycortisol. All other related steroid crossreactivities were $<0.02 \%$.

Samples for AD levels were extracted with ethyl acetate:hexane (3:2), as per the manufacturer's procedure, prior to RIA. The radioligand was ${ }^{125}$-labelled $\mathrm{AD}$, and the bound and unbound steroid was separated by goat anti-rabbit $\gamma$-globulin. The intra-assay coefficients of variation were $8.1 \%, 8.3 \%$ and $7.5 \%$, and the interassay coefficients of variation were $12.6 \%, 7.4 \%$ and $9.7 \%$, for levels of $0.69 \mathrm{ng} / \mathrm{ml}, 2.20 \mathrm{ng} / \mathrm{ml}$ and $6.14 \mathrm{ng} / \mathrm{ml}$, respectively. The AD antiserum cross-reacted $1.79 \%$ with estrone, $0.64 \%$ with testosterone, $0.07 \%$ with progesterone, $4.40 \%$ with DHEA-S, and $3.50 \%$ with DHEA. All other related steroid cross-reactivities were $<0.02 \%$.

The 11ß-OHAD RIA also required prior extraction with ethyl acetate:hexane (1:1). The radioligand was ${ }^{3} \mathrm{H}$-labelled $11 \beta-O H A D$, and the bound and unbound steroid were separated with saturated ammonium sulfate. The intra-assay coefficients of variation were $6.1 \%$ and $6.3 \%$, and the interassay coefficients of variation were $7.2 \%$ and $8.2 \%$, for levels of 115 and $393 \mathrm{ng} / \mathrm{dl}$ respectively (few $11 \beta-\mathrm{OHAD}$ assays were run; therefore, this information is from Inter Sci Diagnostics). The antiserum is very specific for $11 \beta$-OHAD, with little crossreactivity with androstenedione $(2.64 \%)$ and adrenosterone $(0.12 \%)$. All other related steroids cross-reacted $<0.01 \%$.

$B$ determinations required sample extraction and purification prior to the RIA. To $2 \mathrm{ml}$ plasma (pipetted into $40 \mathrm{ml}$ glass centrifuge tubes) was added approximately $500 \mathrm{cpm}$ of ${ }^{3} \mathrm{H}$-corticosterone, $200 \mathrm{ng}$ d-aldosterone21 -acetate (internal standard), and $2 \mathrm{ml}$ double-distilled $\mathrm{H}_{2} \mathrm{O}$. Following a 30-min incubation period at room temperature, the samples were extracted with $10 \mathrm{ml}$ methylene chloride, gently shaken, and centrifuged at $1500 \mathrm{rpm}$ for $20 \mathrm{~min}$. The organic phase was removed and placed in separate clean glass centrifuge tubes. This was repeated two more times, combining all the organic phase for each sample (approximately $30 \mathrm{ml}$ ). The extract then was washed four times with $5 \mathrm{ml} 0.1 \mathrm{~N} \mathrm{NaOH}$, with removal and discard of the $\mathrm{NaOH}$ after each wash. After the final wash, the extract was drawn into a glass syringe, filtered through a $0.22 \mu \mathrm{m}$ durapore filtering system (Millipore, Bedford, MA), and blown down to dryness under nitrogen in a $37^{\circ} \mathrm{C}$ water bath. The sides of the glass tubes then were rinsed with $0.5 \mathrm{ml}$ of ethanol, vortexed, the ethanol transferred to a $1 \mathrm{ml}$ glass test tube, and the tube tightly sealed with parafilm and frozen at $-20^{\circ} \mathrm{C}$ until the purification step.

Purification was done by high-pressure liquid chromatography (HPLC). The HPLC system consisted of a Shimadzu Model LC-4A liquid chromatograph (Shimadzu, Columbia, MD); DuPont UV spectrophotometer detector (DuPont, Wilmington, DE); DuPont Model 860 column compartment; Shimadzu C-R1A Chromatopac integrator; and Pharmacia Model FRAC-100 fraction collector (Pharmacia, Piscataway, NJ). Once the HPLC system was equilibrated, the samples were evaporated to less than $50 \mu 1$, drawn up into a Hamilton syringe, and shot into the HPLC system with a Rheodyne injector. The sample was applied to a $50 \mathrm{~mm} \mathrm{C}-18$ guard column (Jones Chromatography, Columbus, $\mathrm{OH}$ ) and then a $15 \mathrm{~cm}, 5 \mu$ Apex ODS column (Jones Chromatography) at $45^{\circ} \mathrm{C}$ with a flow rate of $2 \mathrm{ml} / \mathrm{min}$, resulting in a pressure of about $140 \mathrm{~kg} / \mathrm{cm}^{2}$. The detector was set at $254 \mathrm{~nm}$ with an absorbance range of $0.01 \mathrm{~A}$. The eluent system was methanol:acetonitrile:water (MeOH:ACN: $\mathrm{H}_{2} \mathrm{O}$ ). The water was double-distilled and deionized, and the methanol and acetonitrile were HPLC grade. All reagents were filtered through a $0.5 \mu \mathrm{m}$ filter and degassed with helium for about $20 \mathrm{~min}$ prior to use. The eluent gradient began at 38:1:61 (MeOH:ACN: $\left.\mathrm{H}_{2} \mathrm{O}\right)$ and went to 55.5:1:43.5 by $20.5 \mathrm{~min}$, and then the column was washed with 38:55:7 eluent for $5 \mathrm{~min}$ and equilibrated again at 38:1:61 for $20 \mathrm{~min}$. The retention time for $B$ under these conditions was about $14 \mathrm{~min}$. The $\mathrm{B}$ fraction was collected in $16 \times 125 \mathrm{~mm}$ glass tubes via the FRAC-100, and the tubes sealed and frozen at $-20^{\circ} \mathrm{C}$ until all samples were purified.

The samples then were lyophylized in a Labconco Model 75040 Freeze Dryer 8 (Labconco, Kansas City, $\mathrm{MO}$ ), reconstituted with $2.5 \mathrm{ml}$ assay buffer, and incubated at room temperature for a minimum of 30 min prior to RIA. From each reconstituted sample a recovery \% was determined and used in calculating the final sample concentration. The average sample recovery $( \pm S D)$ was $50.9 \% \pm 14.1 \%$. The radioligand was ${ }^{3} \mathrm{H}$-corticosterone, and the bound steroid was separated from the unbound by charcoal-dextran. The intra-assay coefficients of variation were $20.7 \%, 9.2 \%$ and $7.2 \%$, and the interassay coefficients of variation were $6.9 \%$, $8.7 \%$ and $8.6 \%$, for corticosterone levels of $2.89 \mathrm{ng} / \mathrm{ml}, 6.57 \mathrm{ng} / \mathrm{ml}$ and $29.7 \mathrm{ng} / \mathrm{ml}$, respectively. The antiserum cross-reacted $100 \%$ with cortisol, $4.5 \%$ with progesterone, $1.7 \%$ with $17 \alpha$-hydroxyprogesterone, $2.5 \%$ with $20 \alpha$-dihydroprogesterone, $4.5 \%$ with deoxycorticosterone, $3.0 \%$ with 11 -deoxycortisol, $3.0 \%$ with aldosterone, $1.3 \%$ with androstenedione, $3.1 \%$ with testosterone, and $1.1 \%$ with dihydrotestosterone. All other related steroid cross-reactivities were $<0.01 \%$. 


\section{Statistical Methods}

Data are reported as mean \pm SD. Steroid hormone responses to exogenous ACTH within each group were analyzed with paired $t$-tests. Comparisons between the MDD and control groups were done with the Student's unpaired $t$-test. When variances between groups were grossly unequal, approximation for the degrees of freedom was determined according to Satterthwaite's formula (Satterthwaite, 1946). For comparisons of three groups (i.e., comparisons made based on DST status), one-way analysis of variance (ANOVA) was used, and when appropriate a Tukey's post hoc test was used to identify between-group differences. Pearson's correlation coefficient was used to estimate the fit between two parameters. Analysis results were considered statistically significant when the confidence level was $\leq 0.05$.

\section{RESULTS}

The symptom rating scale scores and comparisons for the MDD patients and controls and for subgroups of the MDD patients are presented in Table I. Ten of the 35 patients (29\%) completing the DST were DST nonsuppressors (DST-NS) and 25 were suppressors (DST-S). Two of the 30 controls (7\%) were DST-NS.

All steroid hormones demonstrated a marked increase $(p<0.0006)$ following the IV bolus $250 \mu \mathrm{g} \mathrm{ACTH}_{1-24}$ in both the MDD patients and the controls. The time of day the ACTH stimulation test was performed had no significant affect on the basal levels or the responses of the measured steroid hormones. Table II shows the mean steroid levels at baseline, $60 \mathrm{~min}$ after ACTH infusion, and the response (delta) to ACTH infusion for the controls and patients with MDD. The MDD patients had significantly higher baseline $\mathrm{F}(t=2.96 ; \mathrm{df}=74 ; p=0.004)$ and $S$ $(t=2.63 ; \mathrm{df}=59.8 ; p=0.011)$ than the controls and showed a trend towards higher AD baseline levels $(t=1.70 ; \mathrm{df}=69 ; p=0.095)$. Sixty minutes following the ACTH infusion the MDD

(conttnued on Page 488)

TABle I. MEAN \pm SD Hamilton Rating SCALE For DePREsSion (HRSD) AND CARROll RATING SCALE FOR DEPRESSION (CRSD) SCORES AND COMPARISONS FOR THE CONTROLS AND PATIENTS WITH MDD AND SUBGROUPS OF PATIENTS WITH MDD

\begin{tabular}{lccccc}
\hline Group & Total N & \multicolumn{2}{c}{ HRSD } & \multicolumn{2}{c}{ CRSD } \\
\hline Controls & 36 & $2.4 \pm 1.3^{\mathrm{a}}$ & $(28)$ & $2.2 \pm 2.7^{\mathrm{b}}$ & $(32)$ \\
MDD & 40 & $17.6 \pm 6.5$ & $(36)$ & $27.0 \pm 10.9(36)$ \\
DST-NS & 10 & $16.8 \pm 4.7$ & $(8)$ & $26.0 \pm 13.6 \quad(9)$ \\
DST-S & 25 & $16.9 \pm 7.3$ & $(23)$ & $26.7 \pm 10.5(22)$ \\
Bipolar & 7 & $22.4 \pm 8.1^{\mathrm{c}}$ & $(7)$ & $32.3 \pm 8.4 \quad(7)$ \\
Unipolar & 33 & $16.4 \pm 5.6$ & $(29)$ & $25.8 \pm 11.2$ & $(29)$ \\
Psychotic & 17 & $19.6 \pm 17.2$ & $(16)$ & $30.2 \pm 10 \quad(15)$ \\
Nonpsychotic & 23 & $15.9 \pm 5.5$ & $(20)$ & $25.8 \pm 11.3$ & $(21)$ \\
Melancholic & 15 & $20.3 \pm 7.1$ & $(14)$ & $32.0 \pm 8.6^{\mathrm{d}}$ & $(14)$ \\
Nonmelancholic & 8 & $15.3 \pm 3.3$ & $(7)$ & $19.7 \pm 12.4$ & $(7)$ \\
Undetermined & 17 & & & &
\end{tabular}

Number of observations for each measure is in parentheses.

a controls vs. MDD: $t=12.7 ; \mathrm{df}=38.4 ; p=0.0001$

${ }^{b}$ controls vs. $M D D: t=13.2 ; \mathrm{df}=39.7 ; p=0.0001$

${ }^{c}$ bipolar vs. unipolar: $t=2.36 ; \mathrm{df}=34 ; p=0.024$

${ }^{d}$ melancholic vs. nonmelancholic: $t=2.66 ; \mathrm{df}=19 ; p=0.016$ 
TABLE II. MEAN \pm SD STEROID LEVELS AT BASELINE (0) AND 60 MIN POST-250 $\mu \mathrm{G}$ ACTH $(60)$ AND THE CHANGE IN LEVELS $(\Delta)$, IN THE CONTROLS AND PATIENTS WITH MDD

\begin{tabular}{|c|c|c|c|c|}
\hline & & Controls & MDD & $p$ \\
\hline $\begin{array}{l}\mathrm{S} \\
{[\mu \mathrm{g} / \mathrm{dl}]}\end{array}$ & $\begin{array}{c}0 \\
60 \\
\Delta\end{array}$ & $\begin{array}{c}(35) \\
.24 \pm .12 \\
.49 \pm .15 \\
.25 \pm .13\end{array}$ & $\begin{array}{c}(39) \\
34 \pm .22 \\
.68 \pm .31 \\
.33 \pm .21\end{array}$ & $\begin{array}{l}0.011 \\
0.001 \\
0.04\end{array}$ \\
\hline $\begin{array}{l}\mathrm{F} \\
{[\mu \mathrm{g} / \mathrm{dl}]}\end{array}$ & $\begin{array}{c}0 \\
60 \\
\Delta\end{array}$ & $\begin{array}{c}(36) \\
10.5 \pm 4.1 \\
24.5 \pm 6.0 \\
13.9 \pm 5.0\end{array}$ & $\begin{array}{c}(40) \\
13.6 \pm 5.0 \\
33.7 \pm 12.6 \\
20.1 \pm 11.7\end{array}$ & $\begin{array}{l}0.004 \\
0.0001 \\
0.004\end{array}$ \\
\hline $\begin{array}{l}\mathrm{AD} \\
{[\mathrm{ng} / \mathrm{ml}]}\end{array}$ & $\begin{array}{c}0 \\
60 \\
\Delta\end{array}$ & \begin{tabular}{l}
\multicolumn{1}{c}{$(34)$} \\
$1.45 \pm .67$ \\
$2.48 \pm 1.06$ \\
$1.02 \pm .69$
\end{tabular} & $\begin{array}{l}(37) \\
1.75 \pm .82 \\
3.27 \pm 1.28 \\
1.51 \pm .92\end{array}$ & $\begin{array}{l}0.095 \\
0.006 \\
0.014\end{array}$ \\
\hline $\begin{array}{l}17 \alpha-\mathrm{OHP} \\
{[\mathrm{ng} / \mathrm{ml}]}\end{array}$ & $\begin{array}{c}0 \\
60 \\
\Delta\end{array}$ & $\begin{array}{c}(32) \\
.93 \pm .63 \\
2.29 \pm 1.08 \\
1.66 \pm .92\end{array}$ & $\begin{array}{c}(24) \\
1.10 \pm .62 \\
3.65 \pm 1.94 \\
2.55 \pm 1.84\end{array}$ & $\begin{array}{l}0.315 \\
0.021 \\
0.036\end{array}$ \\
\hline $\begin{array}{l}\text { B } \\
{[\mathrm{ng} / \mathrm{ml}]}\end{array}$ & $\begin{array}{c}0 \\
60 \\
\Delta\end{array}$ & $\begin{array}{c}(28) \\
4.33 \pm 4.38 \\
31.8 \pm 15.1 \\
27.5 \pm 15.1\end{array}$ & $\begin{array}{c}(25) \\
5.20 \pm 3.89 \\
32.3 \pm 8.96 \\
27.1 \pm 8.11\end{array}$ & $\begin{array}{l}0.452 \\
0.89 \\
0.908\end{array}$ \\
\hline $\begin{array}{l}\text { 11ß-OHAD } \\
\text { [ng/dl] }\end{array}$ & $\begin{array}{c}0 \\
60 \\
\Delta\end{array}$ & $\begin{array}{c}(9) \\
159.7 \pm 59.8 \\
253.0 \pm 83.0 \\
87.4 \pm 47.9\end{array}$ & \begin{tabular}{l}
\multicolumn{1}{c}{$(17)$} \\
$170.8 \pm 85.5$ \\
$317.9 \pm 120.0$ \\
$147.2 \pm 95.1$
\end{tabular} & $\begin{array}{l}0.733 \\
0.161 \\
0.091\end{array}$ \\
\hline
\end{tabular}

The number measured for each group is in parentheses under the respective columns.

TABLE III. MEAN \pm SD STEROID RESPCNSE (DELTA) TO $250 \mu \mathrm{G}$ ACTH IN CONTROLS WHO WERE DEXAMETHASONE SUPPRESSORS (CONTROLS) AND PATIENTS WITH MDD WHO ARE SUPPRESSORS (DST-S) AND NONSUPPRESSORS (DST-NS)

\begin{tabular}{|c|c|c|c|c|c|}
\hline \multirow[b]{3}{*}{$\mathrm{S}[\mathrm{mg} / \mathrm{dl}]$} & \multirow{2}{*}{ Controls } & \multicolumn{4}{|c|}{ MDD } \\
\hline & & \multicolumn{2}{|l|}{ DST-S } & \multicolumn{2}{|l|}{ DST-NS } \\
\hline & $.26 \pm .14 \quad(28)$ & $.31 \pm .20$ & (25) & $.35 \pm .27$ & (9) \\
\hline $\mathrm{F}[\mu \mathrm{g} / \mathrm{dl}]^{*}$ & $14.8 \pm 4.9^{a}(28)$ & $17.5 \pm 6.1^{\mathrm{a}}$ & (25) & $26.4 \pm 20.5^{b}$ & (10) \\
\hline $\mathrm{AD}[\mathrm{ng} / \mathrm{ml}]$ & $1.12 \pm .71$ & $1.36 \pm .97$ & (24) & $1.83 \pm / 80$ & (9) \\
\hline $17 \alpha-\mathrm{OHP}[\mathrm{ng} / \mathrm{ml}]$ & $1.72 \pm .98 \quad$ & $2.51 \pm 1.93$ & (17) & $2.94 \pm 2.40$ & (7) \\
\hline $\mathrm{B}[\mathrm{ng} / \mathrm{ml}]$ & $27.3 \pm 15.9$ & $25.0 \pm 6.9$ & (15) & $34.1 \pm 7.6$ & (6) \\
\hline $11 \beta-O H A D[\mathrm{ng} / \mathrm{dl}]$ & $87.2 \pm 51.2$ & $145.8 \pm 108.5$ & $(10)$ & $166.8 \pm 89.8$ & (5) \\
\hline
\end{tabular}

Difference among groups with different letters: ${ }^{*} p<0.001$ (Tukey's $p<0.05$ ).

The number measured for each group is in parentheses. 
TABLE IV. MEAN \pm SD STEROID RESPONSE (DELTA) TO $250 \mu \mathrm{G}$ ACTH IN THE PATIENTS WITH MDD GROUPED BY MEDICATION AND THE MOST COMMON DRUG COMBINATTON TREATMENTS WITH FIVE OR MORE OBSERVATIONS

\begin{tabular}{|c|c|c|c|c|c|c|}
\hline Medication & $\begin{array}{c}\mathrm{S} \\
{[\mu \mathrm{g} / \mathrm{dl}]}\end{array}$ & $\underset{[\mu \mathrm{g} / \mathrm{dl}]}{\mathbf{F}}$ & $\begin{array}{c}\text { AD } \\
{[\mathrm{ng} / \mathrm{ml}]}\end{array}$ & $\begin{array}{c}\text { 17 } \alpha \text {-OHP } \\
{[\mathrm{ng} / \mathrm{ml}]}\end{array}$ & $\begin{array}{c}\text { B } \\
{[\mathrm{ng} / \mathrm{ml}]}\end{array}$ & $\begin{array}{c}\text { 11ß-OHAD } \\
\text { [ng/dl] }\end{array}$ \\
\hline \multicolumn{7}{|l|}{ TCA } \\
\hline Off & $.29 \pm .18(10)$ & $26.1 \pm 19.9(11)$ & $1.72 \pm .94(10)$ & $2.55 \pm 1.90(7)$ & $25.3 \pm 8.9(6)$ & $162.8 \pm 95.8(7)$ \\
\hline On & $.35 \pm .22(29)$ & $17.8 \pm 5.5(29)$ & $1.44 \pm .92(27)$ & $2.54 \pm 1.87(17)$ & $27.7 \pm 8.0(19)$ & $136.2 \pm 98.1(10)$ \\
\hline \multicolumn{7}{|l|}{ LI } \\
\hline Off & $.33 \pm .21(25)$ & $20.7 \pm 12.5$ & $1.47 \pm .81(24)$ & $2.72 \pm 1.90(17)$ & $25.8 \pm 7.9(17)$ & $123.4 \pm 79.9(10)$ \\
\hline On & $.35 \pm .22(14)$ & $19.1 \pm 10.7(15)$ & $1.60 \pm 1.13(13)$ & $2.16 \pm 1.73(7)$ & $29.9 \pm 8.4(8)$ & $181.1 \pm 110.7(7)$ \\
\hline \multicolumn{7}{|l|}{ BNZ } \\
\hline Off & $.33 \pm .23(26)$ & $22.1 \pm 13.4(26)$ & $1.43 \pm .86(24)$ & $2.90 \pm 2.14(15)$ & $28.6 \pm 7.5(14)$ & $143.8 \pm 102.8(10)$ \\
\hline On & $.34 \pm .18(13)$ & $16.4 \pm 6.7(14)$ & $1.68 \pm 1.05(13)$ & $1.98 \pm 1.05(9)$ & $25.2 \pm 8.8(11)$ & $152.1 \pm 90.6(7)$ \\
\hline \multicolumn{7}{|l|}{ AP } \\
\hline Off & $.35 \pm .23(27)$ & $19.9 \pm 13.5(28)$ & $1.36 \pm .86(26)$ & $2.83 \pm 2.09(16)$ & $28.3 \pm 9.1(16)$ & $138.5 \pm 87.4(11)$ \\
\hline On & $.31 \pm .17(12)$ & $20.5 \pm 6.5(12)$ & $1.88 \pm 1.01(11)$ & $2.01 \pm 1.12(8)$ & $24.9 \pm 5.7(9)$ & $163.0 \pm 114.9(6)$ \\
\hline $\mathrm{TCA}+\mathrm{LI}$ & $.37 \pm .24(9)$ & $16.0 \pm 5.7(9)$ & $1.48 \pm 1.15(8)$ & $(n<5)$ & $34.9 \pm 4.0(5)$ & $(n<5)$ \\
\hline $\mathrm{TCA}+\mathrm{BNZ}$ & $.34 \pm .19(8)$ & $15.8 \pm 5.2(8)$ & $1.53 \pm .89(8)$ & $1.81 \pm .60(5)$ & $25.8 \pm 8.0(7)$ & $(n<5)$ \\
\hline $\mathrm{TCA}+\mathrm{AP}$ & $.27 \pm .18(7)$ & $18.7 \pm 7.4(7)$ & $1.84 \pm .99(6)$ & $(\mathrm{n}<5)$ & $26.2 \pm 5.2(5)$ & $(n<5)$ \\
\hline $\mathrm{LI}+\mathrm{BNZ}$ & $.33 \pm .18(7)$ & $18.9 \pm 4.9(7)$ & $1.88 \pm 1.19(6)$ & $(n<5)$ & $(n<5)$ & $(n<5)$ \\
\hline $\mathrm{LI}+\mathrm{AP}$ & $.38 \pm .15(6)$ & $15.2 \pm 8.0(7)$ & $1.87 \pm 1.19(6)$ & $(n<5)$ & $(n<5)$ & $(n<5)$ \\
\hline
\end{tabular}

Abbrevlations: TCA = tricyclic antidepressants; $\mathrm{LI}=$ lithium; $\mathrm{BNZ}=$ benzodiazepines; $\mathrm{AP}=$ antipsychotics. Number of observations in parentheses.

Table V. Pearson's Correlation of age with measured steroids at baseline

\begin{tabular}{|c|c|c|c|}
\hline & $\mathbf{n}$ & $r$ & $p$ \\
\hline \multicolumn{4}{|l|}{ Controls } \\
\hline $\mathrm{S}$ & 35 & -.586 & 0.0002 \\
\hline $\mathrm{F}$ & 36 & -.410 & 0.013 \\
\hline $\mathrm{AD}$ & 34 & -.650 & 0.0001 \\
\hline $17 \alpha-\mathrm{OHP}$ & 32 & -.554 & 0.001 \\
\hline B & 28 & -.522 & 0.004 \\
\hline $11 \beta-O H A D$ & 9 & +.309 & 0.419 \\
\hline \multicolumn{4}{|l|}{ MDD } \\
\hline $\mathrm{S}$ & 39 & -.385 & 0.016 \\
\hline F & 40 & -.123 & 0.450 \\
\hline $\mathrm{AD}$ & 37 & -.409 & 0.012 \\
\hline $17 \alpha-\mathrm{OHP}$ & 24 & -.369 & 0.076 \\
\hline B & 25 & -.205 & 0.326 \\
\hline $11 \mathrm{~b}-\mathrm{OHAD}$ & 17 & -.055 & 0.834 \\
\hline
\end{tabular}


TABLE VI. CORRELATION OF STEROID LEVELS WITH EACH OTHER/ $P$ VALUE FOR CORRELATION COEFFICIENT AT BASELINE

\begin{tabular}{|c|c|c|c|c|c|}
\hline & $\mathbf{F}$ & $\mathbf{A D}$ & $17 \alpha-\mathrm{OHP}$ & B & 11ß-OHAD \\
\hline \multicolumn{6}{|l|}{ Controls } \\
\hline$S$ & $\begin{array}{c}.586 / .0002 \\
(35)\end{array}$ & $\begin{array}{c}.668 / .0001 \\
(34)\end{array}$ & $\begin{array}{c}.726 / .0001 \\
(32)\end{array}$ & $\begin{array}{c}.534 / .0034 \\
(28)\end{array}$ & $\begin{array}{c}.211 / .587 \\
\text { (9) }\end{array}$ \\
\hline F & & $\begin{array}{c}.405 / .017 \\
(34)\end{array}$ & $\begin{array}{c}.521 / .0023 \\
(32)\end{array}$ & $\begin{array}{c}.683 / .0001 \\
(28)\end{array}$ & $\begin{array}{c}.651 / .056 \\
(9)\end{array}$ \\
\hline$A D$ & & & $\begin{array}{c}.695 / .0001 \\
(31)\end{array}$ & $\begin{array}{c}.435 / .021 \\
(28)\end{array}$ & $\begin{array}{c}.258 / .502 \\
(9)\end{array}$ \\
\hline $17 \alpha-\mathrm{OHP}$ & & & & $\begin{array}{c}.611 / .0009 \\
(26)\end{array}$ & $\begin{array}{c}.343 / .366 \\
(9)\end{array}$ \\
\hline B & & & & & $\begin{array}{c}.325 / .432 \\
(8)\end{array}$ \\
\hline \multicolumn{6}{|l|}{ MDD } \\
\hline$S$ & $\begin{array}{c}.021 / .901 \\
(39)\end{array}$ & $\begin{array}{c}.171 / .312 \\
(37)\end{array}$ & $\begin{array}{c}.084 / .697 \\
(24)\end{array}$ & $\begin{array}{c}.228 / .272 \\
(25)\end{array}$ & $\begin{array}{c}-.285 / .268 \\
(17)\end{array}$ \\
\hline$F$ & & $\begin{array}{c}.343 / .038 \\
(37)\end{array}$ & $\begin{array}{c}-.047 / .826 \\
(24)\end{array}$ & $\begin{array}{c}.368 / .070 \\
(25)\end{array}$ & $\begin{array}{c}.073 / .781 \\
(17)\end{array}$ \\
\hline $\mathrm{AD}$ & & & $\begin{array}{c}.161 / .453 \\
(24)\end{array}$ & $\begin{array}{c}.311 / .130 \\
(25)\end{array}$ & $\begin{array}{c}.350 / .168 \\
(17)\end{array}$ \\
\hline $17 \alpha-\mathrm{OHP}$ & & & & $\begin{array}{c}.196 / .393 \\
(21)\end{array}$ & $\begin{array}{c}-.0092 / .973 \\
(16)\end{array}$ \\
\hline B & & & & & $\begin{array}{c}.407 / .132 \\
(15)\end{array}$ \\
\hline
\end{tabular}

Number of observations is in parentheses.

patients had significantly higher $\mathrm{F}(t=4.15 ; \mathrm{df}=57.0 ; p=0.0001), \mathrm{S}(t=3.41 ; \mathrm{df}=56.2$; $p=0.001), \mathrm{AD}(t=2.84 ; \mathrm{df}=69 ; p=0.006)$, and $17 \alpha-\mathrm{OHP}(t=2.43 ; \mathrm{df}=33.7 ; p=0.021)$ levels than the controls. The MDD patients had a significantly greater response (delta) to exogenous ACTH for $\mathrm{F}(t=3.02 ; \mathrm{df}=53.8 ; p=0.004), \mathrm{S}(t=2.10 ; \mathrm{df}=63.3 ; p=0.040)$, AD $(t=2.53$; $\mathrm{df}=69 ; p=0.014)$, and $17 \alpha-\mathrm{OHP}(t=2.19 ; \mathrm{df}=31.6 ; p=0.036)$ than the controls and had a trend toward a greater $11 \beta-O H A D$ response $(t=1.76 ; \mathrm{df}=24 ; p=0.091)$ (Table II \& Fig. 1).

When the MDD patients were subcategorized by DST suppression status and compared to only the controls who suppressed normally following dexamethasone, the patients with MDD who were DST-NS had the greatest $\mathrm{F}$ response $(\mathrm{F}=5.65 ; \mathrm{df}=2,60 ; p=0.0057)$. In general, the MDD DST-NS patients had the greatest response for all the steroids, followed by the MDD DST-S and the controls except for B where the MDD DST-S had the lowest response (Table III). MDD patients with psychosis had a significantly greater $11 \beta-O H A D$ response $(\mathrm{n}=6: 233.8 \pm 57.9 \mathrm{ng} / \mathrm{dl})$ than those with nonpsychotic MDD $(\mathrm{n}=11: 99.9 \pm 76.4 \mathrm{ng} / \mathrm{dl})$ $(t=3.72 ; \mathrm{df}=15 ; p=0.002)$. No other significant differences based on the presence of psychosis were noted. No significant hormone differences were observed between patients with 
unipolar and bipolar MDD or in those with melancholic versus those without melancholic depression.

The most common treatment medication in the MDD patients was tricyclic antidepressants (29). Other treatment drugs were lithium (15), benzodiazepines (14), antipsychotics (12), and monoamine oxidase inhibitors (4), or a combination of psychotropic medications. The effect that these medications may have on the steroid hormone response to exogenous ACTH is presented in Table IV.

All compounds measured, with the exception of $11 \beta-O H A D$, decreased with age in the control subjects; only $S$ and $A D$ demonstrated a similar, but not nearly as robust, relationship in the MDD patients (Table V). Except for $11 \beta-O H A D$, all of the steroid hormones were significantly positively correlated with each other at baseline in the controls (Table VI). 11 $\beta$ OHAD also demonstrated a positive correlation with the other steroids but was measured in fewer subjects and did not reach significance. This relationship is reflected in the MDD patients only between $\mathrm{AD}$ and F. Sixty minutes following the infusion of $\mathrm{ACTH}_{\mathbf{1}}$ only S and $\mathrm{AD}(r=.438 ; p=0.01), \mathrm{S}$ and $17 \alpha-\mathrm{OHP}(r=.484 ; p=0.005)$ and $\mathrm{AD}$ and $17 \alpha-\mathrm{OHP}$ $(r=397 ; p=0.027)$ remained significantly correlated in the controls. None of the compounds were significantly correlated with each other in the MDD patients 60 min after $\mathrm{ACTH}_{1-24}$.

Only the response of $S$ to exogenous ACTH was significantly correlated with the duration of illness in the MDD patients $(r=-.392 ; p=0.014)$. Likewise, the severity of symptoms was significantly positively correlated only with the response of $11 \beta-O H A D$ to ACTH (HRSD: $r=.550 ; p=0.034 ;$ CRSD: $r=.482 ; p=0.059$ ).

\section{DISCUSSION}

The ACTH stimulation test has been used previously in assessing adrenocortical responsiveness in depressed patients (Holsboer et al., 1984), in depressed patients retested following treatment or recovery from their illness (Sclare \& Grant, 1972; Endo et al., 1974; Gerken \& Holsboer, 1986; Amsterdam et al., 1987a), and in normal controls compared to depressed patients (Carpenter \& Bunney, 1971; Amsterdam et al., 1983; 1986; Jaeckle et al., 1987; Fang et al., 1988a). With the exception of a few studies, however, investigators have limited their studies to the cortisol (F) response. In the few studies that have measured steroid hormones other than F (Holsboer et al., 1984; Gerken \& Holsboer, 1986), normal controls were not included. In this study we measured $F, 11$-deoxycortisol (S), corticosterone (B), 17 $\alpha$-hydroxyprogesterone (17 $\alpha$-OHP), androstenedione (AD), and $11 \beta$-hydroxyandrostenedione (11 $\beta$ OHAD) to further address adrenal responsiveness following acute ACTH stimulation and to investigate its effect on the biosynthesis of adrenal steroids in depressed patients. Where these hormones occur in the production and metabolism of corticosteroids is summarized in Fig. 2.

We report augmented responses of $\mathrm{F}, \mathrm{S}, \mathrm{AD}, 17 \alpha-\mathrm{OHP}$, and $11 \beta-\mathrm{OHAD}$, but not of $\mathrm{B}$, to acute stimulation with a supraphysiological dose of ACTH in a group of patients with MDD compared to normal controls. Since some of the subjects in this study were also included in a study by Jaeckle et al. (1987) and the methods were the same, the F response is similar to that which Jaeckle et al. reported. The increased $\mathrm{F}$ response in the depressed patients is also in agreement with the findings of Amsterdam et al. (1983) who also used a dose of $250 \mu \mathrm{g} \mathrm{ACTH}$ but administered it in the morning. However, others have not observed this difference (Carpenter \& Bunney, 1971; Fang et al., 1988a). This difference is most likely due to differences in the methods used. Carpenter and Bunney (1971) infused the ACTH continuously over a 4-hr morning period rather than giving an IV bolus. Fang et al. (1988a) first suppressed endogenous 
ACTH with dexamethasone and then stimulated with a much smaller dose $(<4 \mu \mathrm{g})$, also in the morning.

The studies of Amsterdam et al. (1983; 1986; 1987a) and Jaeckle et al. (1987) suggested that the differences found in the $F$ response may be due to an increased adrenal sensitivity to ACTH in depressed patients. Fang et al. (1988a; 1988b) responded that when using a supraphysiological dose $(250 \mu \mathrm{g} \mathrm{ACTH})$, adrenal secretory capacity is more likely being measured rather than adrenal sensitivity. It is possible, therefore, that the increased steroid response in the depressed patients is due to adrenal hypertrophy, since chronic stimulation with ACTH is known to increase adrenal size. Thus stimulation with a supraphysiological dose of exogenous ACTH to enlarged adrenal glands theoretically would result in greater steroid production. In fact, computed tomography scans of adrenal glands in depressed patients have shown increased adrenal volume in $50 \%$ of the patients studied (Amsterdam et al., 1987b). Increased adrenal weight also has been reported in suicide victims compared to persons with no known history of psychiatric illnesses dying from traumatic injuries or sudden medical complications (DoroviniZis \& Zis, 1987). Because in the present study we also used a supraphysiological dose of ACTH, we cannot conclude that the differences seen between the MDD patients and controls were due to an increase in adrenal responsiveness vs. hypertrophy of the adrenal glands. Only further investigation of steroid responsiveness to more physiological doses of exogenous ACTH, and/or endogenous ACTH stimulated via other provocative tests such as the corticotropin-releasing hormone stimulation test or insulin-induced hypoglycemia, can clarify this point.

$\mathrm{B}$ was the only steroid measured that did not show an augmented response compared to the controls. It is possible that, since the measurement of B was the most difficult because it required such extensive sample preparation prior to analysis, differences could be explained on the basis of laboratory error. However, one would have expected the error to have been equal in both the controls and the patients with MDD. Furthermore, while controls were not included in the studies of Holsboer et al. (1984) and Gerken and Holsboer (1986), our B levels are in agreement with the levels they reported. An alternative explanation is that the production of $B$ becomes maximally stimulated (approximately $32 \mathrm{ng} / \mathrm{ml}$ ) with a supraphysiological dose of ACTH. In depressed patients this favors $17 \alpha$-hydroxylation of $\Delta^{5}$-pregnenolone and progesterone. Glucocorticoid and adrenal androgen production would continue to increase, but mineralcorticoid production would not.

Finally, the data in Table III suggest that the augmented hormone responses may be associated with DST status. Previous studies have reported significant correlations of the response of $\mathrm{F}$ to $250 \mu \mathrm{g} \mathrm{ACTH}$ with post-DST $1600 \mathrm{~h}$ F levels (Holsboer et al., 1984; Jaeckle et al., 1987). Therefore, had DST-NS patients, i.e., those with the highest production of corticosteroids, been better represented in our study, it is likely that the differences in hormone response between the MDD patients and controls would be more robust, including the response of $B$. In fact, a greater B response to exogenous ACTH has previously been reported in DST-NS depressed patients, but only when retested following recovery from illness (Gerken \& Holsboer, 1986).

Another way that our data could be interpreted is that depressed patients have adrenal hyper-responsiveness by way of enhanced activity or increased synthesis of enzymes involved in the biosynthesis of corticosteroids and adrenal androgens, particularly those under the control of ACTH, resulting in hypercortisolemia. ACTH affects steroidogenesis at two levels. First, acute ACTH stimulation causes a rapid increase in steroidogenesis by increasing the rate of conversion of cholesterol to $\Delta^{5}$-pregnenolone, the rate-limiting step in steroidogenesis (Fig. 2), by increasing the amount of mitochondrial cholesterol (substrate) bound to cytochrome 

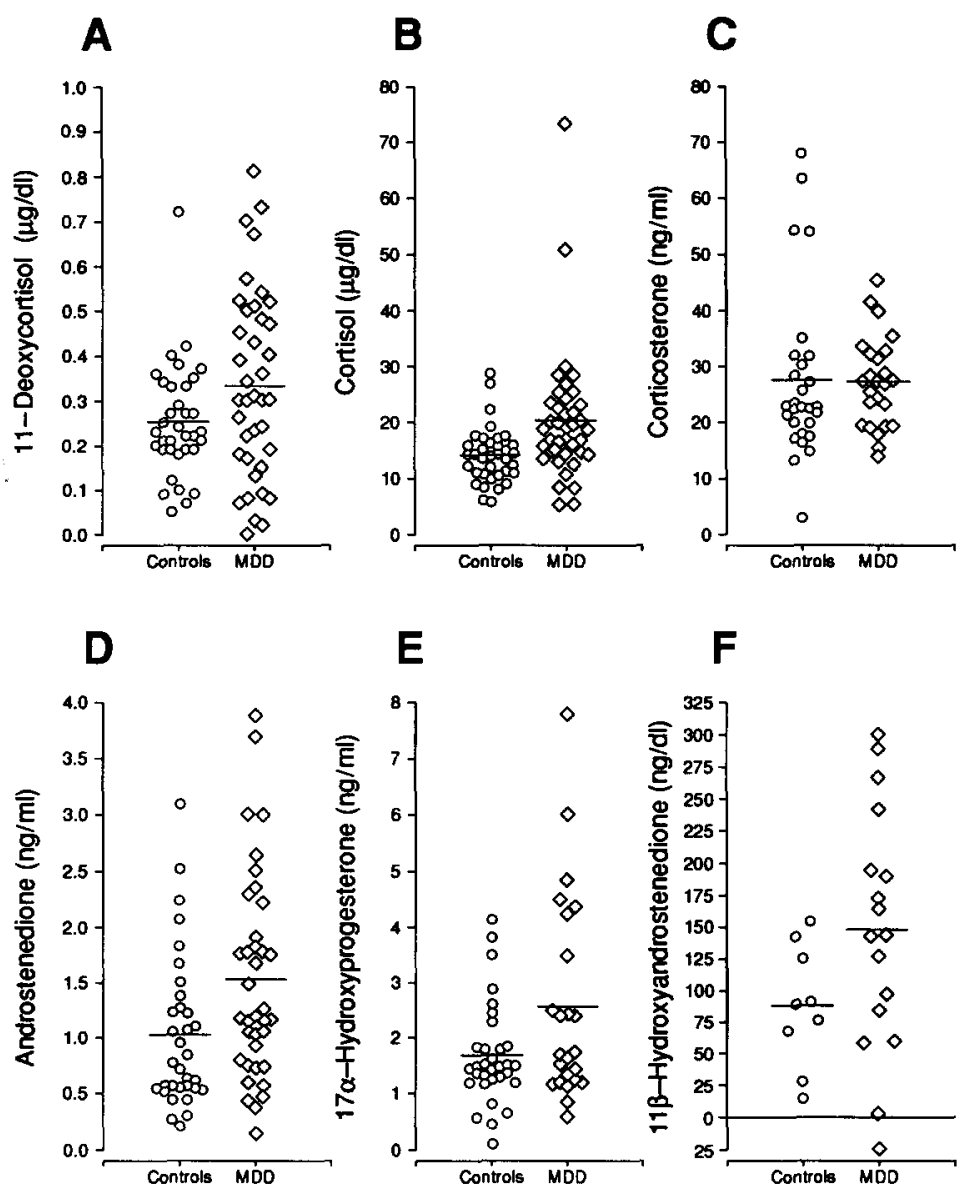

FIG. 1: Scattergram of the change in hormone levels after ACTH $_{1-24}$ in controls and patients with MDD. (A) 11-Deoxycortisol, (B) Cortisol, (C) Corticosterone, (D) Androstenedione, (E) 17 $\alpha$-Hydroxyprogesterone, (F) 11 $\beta$-Hydraxyandrostenedione.

P-450 to be converted to $\Delta^{5}$-pregnenolone (Simpson \& Waterman, 1983). An acute supraphysiological dose of ACTH therefore would cause a marked increase in the adrenal steroids which was observed in both the controls and depressed patients in this study. Second, ACTH has a tropic affect on steroidogenesis by maintaining adequate levels of steroidogenic enzymes (Simpson \& Waterman, 1983). Several of these steroidogenic enzymes require cytochrome P450 , a heme-containing enzyme found in the adrenocortical mitochondria and microsomes, as well as in other organs (Rapp, 1986). Synthesis of mitochondrial cytochrome P-450 $\mathrm{SCC}$ (cholesterol side chain cleavage) (DuBois et al., 1981) and $\mathrm{P}-450_{11 \beta}$ (11ß-hydroxylase) (Kramer et al., 1983a), and microsomal cytochrome $\mathrm{P}^{-450} \mathrm{C}_{\mathrm{C} 21}$ (21-hydroxylase) (Funkenstein et al., 1983) and $\mathrm{P}-450_{17 \alpha}(17 \alpha$-hydroxylase) (Zuber et al., 1985) have been shown to increase in ACTH-treated cells. Furthermore, increased $17 \alpha$-hydroxylase activity has been reported in in vitro studies utilizing cultured bovine adrenocortical cells treated with ACTH (McCarthy et al., 1983; Simpson \& Waterman, 1983; Zuber et al., 1985) and in in vivo studies with ACTH- 


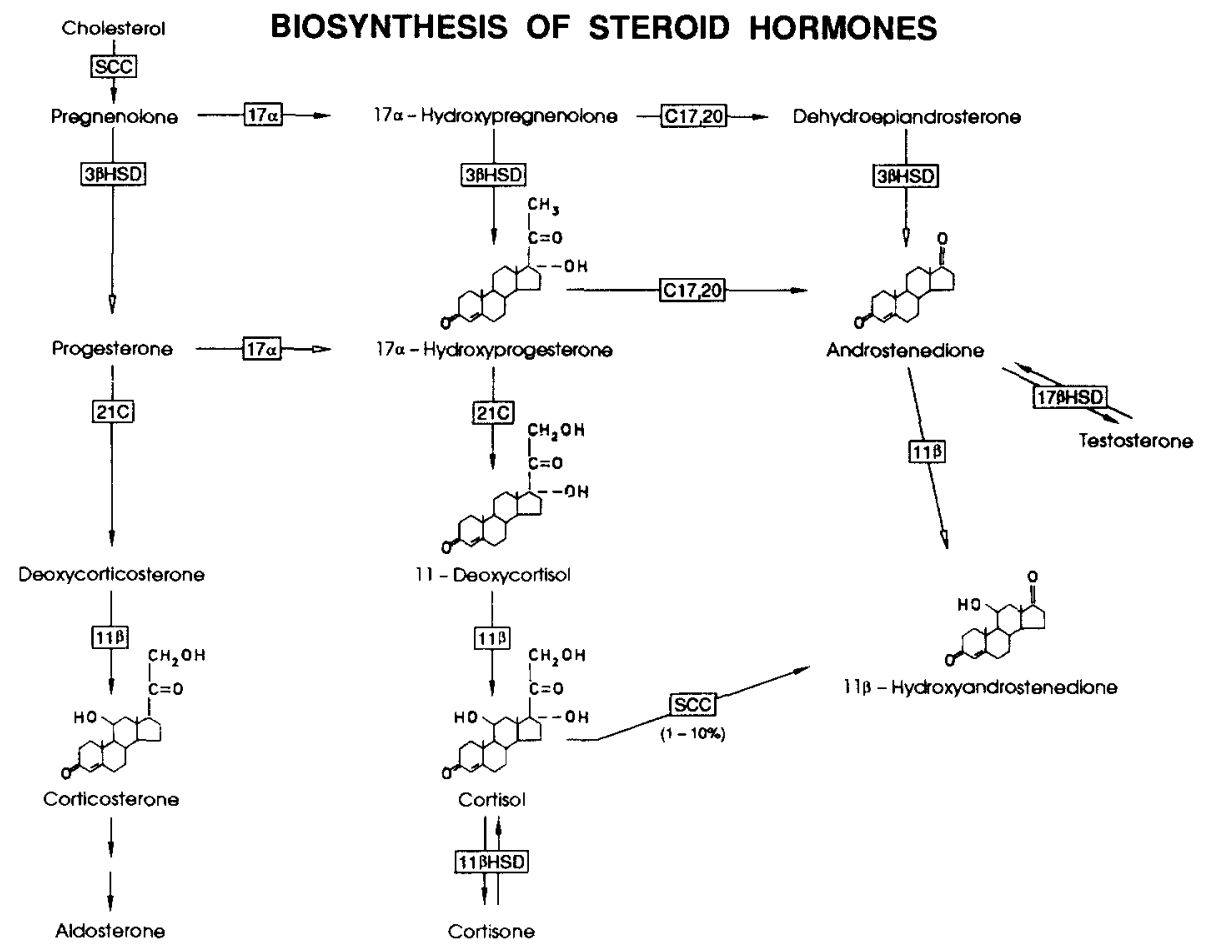

FIG. 2: Blosynthests of steroid hormones. Major pathways are indicated by the solid arrowheads, minor pathways are indicated by the open arrowheads, and multiple reactions are indicated by two consecutive arrows. Abbreviations: SCC = side chain cleavage; $17 \alpha=17 \alpha$ hydroxylase: $3 \beta \mathrm{HSD}=5$-ene-3 $\beta$-hydroxysterold dehydrogenase and 3 -oxosteroid isomerase; $\mathrm{C} 17,20=17,20$ lyase; $\mathrm{C} 21=21$-hydroxylase; $11 \beta=11 \beta$-hydroxylase; $17 \beta H S D=17 \beta$-hydroxysteroid dehydrogenase; $11 \beta \mathrm{HSD}=11 \beta$-hydroxysteroid dehydrogenase.

treated rabbits (Fevold et al., 1978). ACTH apparently does not have this same effect on 21hydroxylase (Funkenstein et al., 1983) or 11 $\beta$-hydroxylase (Kathol et al., 1987). However, Kramer et al. (1983b) reported that secretion of $17 \alpha$-hydroxysteroids and $\mathrm{C}_{19}$ steroids (i.e., androgens) was enhanced further by the action of ACTH to increase $17 \alpha$-hydroxylase activity and possibly 17,20 lyase. The possibility of 17,20 lyase activity being enhanced by ACTH in conjunction with $17 \alpha$-hydroxylase is very likely since 17,20 lyase and $17 \alpha$-hydroxylase are now thought to be localized on the same polypeptide chain (Nakajin \& Hall, 1981) and associated with one protein (Nakajin $e t$ al., 1981). The action of $17 \alpha$-hydroxylase lies at an important juncture in the biosynthetic pathway of adrenal steroids. Without it, glucocorticoids and adrenal androgens would be nonexistent. Likewise, 17,20 lyase is necessary for further conversion of $17 \alpha-\mathrm{OHP}$ and $17 \alpha$-hydroxypregnenolone to the androgens. Therefore, any enhancement of $17 \alpha$-hydroxylase and 17,20 lyase activities or increased production of cytochrome $\mathrm{P}-450_{\mathrm{Cl} 17}(17 \alpha$-hydroxylase/17,20 lyase) could potentially favor increased production and secretion of the $17 \alpha$-hydroxysteroids and adrenal androgens.

Elevated levels of ACTH in dexamethasone-resistant depressed patients have been reported by several investigators (Fang et al., 1981; Reus et al., 1982; 1983; Kalin et al., 1982). Pfohl et al. $(1985 \mathrm{a} ; 1985 \mathrm{~b})$ reported an increase in ACTH levels in depressed patients over a 24-hr 
period, with significant increases at varying times compared to controls. It is possible, then, that in depressed patients chronically higher circulating levels of ACTH are maintaining increased amounts of steroidogenic enzymes by stimulating synthesis of cytochrome P-450 and enhancing the enzyme activity of $17 \alpha$-hydroxylase and 17,20 lyase. Therefore, when acute ACTH stimulation occurs in depressed patients, greater amounts of enzymes are available for the necessary conversions in the steroidogenic pathways, causing an increased production and secretion of the steroids. Furthermore, if $17 \alpha$-hydroxylase and 17,20 lyase activities are enhanced due to the chronically elevated ACTH while 5-ene-3 $\beta$-hydroxysteroid dehydrogenase and 3-oxosteroid isomerase are not, then the steroids converted from $17 \alpha-O H P$ (i.e., F, S, AD, etc.) would demonstrate a greater response, while the mineralcorticoid pathway (i.e., B) would respond less robustly. Enhanced $17 \alpha$-hydroxylase and 17,20 lyase activities are consistent with the differences we found in the baseline data. Levels of $F, S$, and $A D$ were elevated in the depressed patients compared to the controls.

Another explanation of our data could be a question of stimulated thresholds. It is possible that each adrenal steroid has a different responsive threshold to ACTH and that depressed patients have higher thresholds than controls. However, since we only tested a single, supraphysiological dose of ACTH, this explanation cannot not be adequately addressed here.

Our data also suggest that there is a change in the way depressed patients respond to ACTH in other ways besides preferential production of $17 \alpha$-hydroxysteroids and adrenal androgens. There also was loss of the relationship among the basal levels of the steroids measured. This lost relationship could be ascribed simply to the increased variance in the depressed individuals; however, this in itself is a difference between controls and patients with depression, and found in numerous endocrine evaluations in the literature, which needs an explanation. Both controls and depressed patients in this study had their testing performed in the same structured environment. Is there something about their life circumstances, depressive treatment, or emotional state which has led to a less-coordinated production of adrenal hormones?

Perhaps a more important finding in our study was the consistent negative correlation between age and basal hormone levels in the controls. This negative relationship was largely lost in the patients with depression. These findings support what has been previously reported regarding age and other measures of corticosteroid production. Normal controls had no change, or a reduction, of glucocorticoid excretion with increasing age (Hamburger, 1954; Juselius \& Kenny, 1974; Kathol et al., 1989). Findings on post-dexamethasone F levels also suggest either no effect of age or a decrease with age (Tourigny-Rivard et al., 1981; Lewis et al., 1984), although other studies question whether this is the case (Oxenkrug et al., 1983). Patients with depression, on the other hand, have consistently been found to have an increase in urinary glucocorticoid excretion or DST nonsuppression with advancing age (Jacobs et al., 1984; Sharma et al., 1988; Kathol et al., 1989). Many studies also have reported significantly positive correlations of age with post-dexamethasone F levels in depressed patients (Asnis et al., 1981; Lewis et al., 1984; Nelson et al., 1984; Holsboer et al., 1986; Whiteford et al., 1987; Maes et al., 1990) as well as with baseline F levels (Asnis et al., 1981; Whiteford et al., 1987). Still others have reported a significant positive correlation of age with the $F$ response to human corticotropin-releasing hormone stimulation in depressed patients but not in controls (von Bardeleben \& Holsboer, 1989). The fact that our patients with depression lost the negative relationship of the hormones with age is in the predicted direction for this group, even though a positive correlation was not found. This suggests that there is a consistent difference between those with depression who, if anything, increase corticosteroid production with age, and those without a history of depression, who generally show a decrease in corticosteroid production with age. 
Our study is not without its problems. All but one of our patients were on one or more psychotropic drugs, and we cannot rule out the possibility that these drugs contributed to the differences observed. However, DST-NS depressed patients who are treated with antidepressants have been reported to suppress normally following treatment (Holsboer et al., 1982; Greden et al., 1983). This suggests that if these drugs were affecting the adrenal response, then it is most likely that their effect would have been to diminish the differences by lowering the $F$, and very likely the other steroid, levels towards those seen in the controls. Since these studies only measured F, however, the possibility of these drugs affecting the other steroid concentrations remains unanswered. Only further research into the effects these drugs have on adrenal responsiveness can clarify this point. Another contributing factor is that our female subjects were not controlled for their menstrual cycle. This may constitute a problem when interpreting the $17 \alpha$ OHP data, because of the low levels before ovulation and the rise in progesterone and $17 \alpha-$ OHP levels from the corpus luteum following ovulation. However, when the male patients and controls were compared, the differences remained. In any case, this should probably be taken into account when measurements of $17 \alpha-\mathrm{OHP}$ are done.

In conclusion, we report increased adrenal steroid responses for $S, A D, 17 \alpha-O H P$, and $11 \beta$ OHAD, but not B, similar to those previously reported for F (Jaeckle et al., 1987) in depressed patients compared to controls following acute ACTH stimulation. Any of these could be more closely related to the development of depression or characteristic symptoms of depression than F. Interestingly, androgens also have been independently related to depressive symptoms in those taking synthetic androgens (Pope \& Katz, 1987; 1988; Perry et al., 1989). Our preliminary findings with $11 \beta$-OHAD suggest that it may have a relationship to psychosis in depression. Increased production of $17 \alpha$-hydroxysteroids and adrenal androgens may be due to an enhanced $17 \alpha$-hydroxylase and 17,20 lyase, activity or increased synthesis of cytochrome P$450_{\mathrm{C} 17}$, following chronic higher levels of ACTH in depressed patients. Alternatively, the augmented responses could be related to a defect in the negative feedback mechanism of corticosteroids on pituitary and hypothalamic function, since the DST-NS depressed patients consistently had the greatest steroid responses to exogenous ACTH. However, the possibility that psychotropic drugs influenced the augmented responses cannot be ruled out, since all but one of the patients with MDD were on one or more psychotropic drugs.

During the basal state the depressed patients showed a loss of uniform relationships among the adrenal steroids and a loss of the age-related decrease in steroid levels that occurred in the controls. The lost negative correlation of age with basal steroid levels may suggest a genetic predisposition to increased corticosteroid production, which is age-related. While evidence is plentiful suggesting that hypercortisolemia in depression may be caused by abnormalities in the limbic and hypothalamic neuroregulatory systems, abnormalities in peripheral systems also may be involved. This study presents data that warrants further investigation of the role of cortisol precursors and metabolites in depressive illness.

Acknowledgements: This study was supported by grant MH-39259 from the National Institute of Mental Health. Partial support also was provided by grant RR59 from the General Clinical Research Centers Program, Division of Research Resources, National Institutes of Health. The authors wish to acknowledge Jane Meller, Phillip Ecklund and Ana Lopez for their assistance in data collection and subject recruitment and Michael Suelzer for statistical consultation. 


\section{REFERENCES}

American Psychiatric Association (1980) Diagnostic and Statistical Manual, Third Edition. APA Press, Washington DC.

Amsterdam J, Winokur A, Abelman E, Lucki I, Rickels K (1983) Cosyntropin ( ACTH $_{1-24}$ ) stimulation test in depressed patients and healthy subjects. Am J Psychiatry 140: 907-909.

Amsterdam JD, Maislin G, Abelman E, Berwish N, Winokur A (1986) Adrenocortical responsiveness to the ACTH stimulation test in depressed patients and healthy volunteers. $J$ Affect Disord 11: 265-274.

Amsterdam JD, Maislin G, Droba M, Winokur A (1987a) The ACTH stimulation test before and after clinical recovery from depression. Psychiatry Res 20: 325-336.

Amsterdam JD, Marinelli DL, Arger P, Winokur A (1987b) Assessment of adrenal gland volume by computed tomography in depressed patients and healthy volunteers: a pilot study. Psychiatry Res 21: 189-197.

Arana GW, Mossman D (1988) The dexamethasone suppression test and depression. Approaches to the use of a laboratory test in psychiatry. Neurol Clin 6: 21-39.

Asnis GM, Sachar EJ, Halbreich U, Nathan RS, Novacenko H, Ostrow LC (1981) Cortisol secretion in relation to age in major depression. Psychosom Med 43: 235-242.

Biglieri EG, Shambelan M, Slaton PE Jr (1969) Effect of adrenocorticotropin on desoxycorticosterone, corticosterone and aldosterone excretion. J Clin Endocrinol Metab 29: 1090-1101.

Carpenter WT, Bunney WE Jr (1971) Adrenal cortical activity in depressive illness. Am J Psychiatry 128: $31-40$.

Carroll B, Feinberg M, Smouse M, Rawson S, Greden J (1981) The Carroll Rating Scale for Depression: I. Development, reliability, and validation. Brit J Psychiatry 138: 194-200.

Crane MG, Harris JJ (1966) Deoxycorticosterone secretion rates in hyperadrenocorticism. J Clin Endocrinol Metab 26: 1135-1143.

De Kloet ER, Reul JMHM (1987) Feedback action and tonic influence of corticosteroids on brain function: a concept arising from the heterogeneity of brain receptor systems. Psychoneuroendocrinology 12: 83-105.

De Kloet ER, Ratka A, Reul JMHM, Sutanto W, Van Eekelen JAM (1987) Corticosteroid receptor types in brain: regulation and putative function. Ann N Y Acad Sci 512: 351-361.

Devanand DP, Pandurangi AK, Dewan MJ (1984) False-positive dexamethasone suppression test results related to antipsychotic drug withdrawal: case report. Clin Psychiatry 45: 275-276.

Dilsaver SC, Greden JF (1984) Effects of antidepressant withdrawal on the dexamethasone suppression test. Psychiatry Res 14: 111-122.

Dorovini-Zis K, Zis AP (1987) Increased adrenal weight in victims of violent suicide. Am J Psychiatry 144: 1214-1215.

DuBois RN, Simpson ER, Waterman MR (1981) Induction of synthesis of cholesterol side chain cleavage cytochrome P-450 by adrenocorticotropin in cultured bovine adrenocortical cells. $J$ Biol Chem 256: $7000-7005$.

Endo M, Endo J, Nishikubo M, Yamaguchi T, Hatotani N (1974) Endocrine studies in depression. In: Hatotani N (Ed) Psychoneuroendocrinology. Karger, Basel, pp 22-31.

Fang VS, Tricou BJ, Robertson A, Meltzer HY (1981) Plasma ACTH and cortisol levels in depressed patients: relation to dexamethasone suppression test. Life Sci 29: 931-938.

Fang VS, Jiang H-K, Lu R-B, Rose RP, Luchins DJ (1988a) Cortisol response to ACTH infusion in depressed patients: comparison with age-, sex-, and weight-matched normal controls. Psychoneuroendocrinology 13: 497-503.

Fang VS, Jiang H-K, Rose RP, Luchins DJ (1988b) Adrenal gland in major depression: enlarged capacity or enhanced sensitivity? [Letter to the Editor] Arch Gen Psychiatry 45: 964-965.

Fevold HR, Wilson PL, Slanina SM (1978) ACTH-stimulated rabbit adrenal 17-hydroxylase. Kinetic properties and a comparison with those of 3ß-hydroxysteroid dehydrogenase. J Steroid Biochem 9: 1033-1041.

Funkenstein B, McCarthy JL, Dus KM, Simpson ER, Waterman MR (1983) Effect of adrenocorticotropin on steroid 21-hydroxylase synthesis and activity in cultured bovine adrenocortical cells. $J$ Biol Chem 258: 9398-9405.

Gerken A, Holsboer F (1986) Cortisol and corticosterone response after syn-corticotropin in relationship to dexamethasone suppressibility of cortisol. Psychoneuroendocrinology 11: 185-194. 
Greden J, Gardner R, King D, Grunhaus L, Carroll B, Kronfol Z (1983) Dexamethasone suppression tests in antidepressant treatment of melancholia: the process of normalization and test-retest reproducibility. Arch Gen Psychiatry 40: 493-500.

Hamburger C (1954) Six years' daily 17-ketosteroid determinations in one subject. Seasonal variations and independence of volume of urine. Acta Endocrinol 17: 116-127.

Hamilton M (1960) A rating scale for depression. J Neurol Neurosurg Psychiat 23: 56-62.

Harris JJ, Hoegel C, Crane MG (1967) Deoxycorticosterone secretion rates before and during metyrapone administration in normal subjects. J Clin Endocrinol Metab 27: 106-113.

Holsboer F, Liebl R, Hofschuster E (1982) Repeated dexamethasone suppression test during depressive illness: normalization of the test results compared with clinical improvement. J Affect Disord 4: 93-101.

Holsboer F, Müller OA, Doerr HG, Sippell WG, Stalla GK, Gerken A, Steiger A, Boll E, Benker O (1984) ACTH and multisteroid responses to corticotropin-releasing factor in depressive illness: relationship to multisteroid responses after ACTH stimulation and dexamethasone suppression. Psychoneuroendocrinology 9: 147-160.

Holsboer F, Philipp M, Steiger A, Gerken A (1986) Multisteroid analysis after DST in depressed patients - a controlled study. J Affect Disord 10: 241-249.

Jacobs S, Mason J, Kosten T, Brown S, Ostfeld A (1984) Urinary-free cortisol excretion in relation to age in acutely stressed persons with depressive symptoms. Psychosom Med 46: 213-221.

Jaeckle RS, Kathol RG, Lopez JF, Meller WH, Krummel SJ (1987) Enhanced adrenal sensitivity to exogenous cosyntropin $\left(\mathrm{ACTH}_{\alpha 1-24}\right)$ stimulation in major depression. Arch Gen Psychiatry 44: 233-240.

Juselius RE, Kenny FM (1974) Urinary free cortisol excretion during growth and aging: correlation with cortisol production rate and 17-hydroxycorticosteroid excretion. Metabolism 23: 847-852.

Kalin NH, Weiler SJ, Shelton SE (1982) Plasma ACTH and cortisol concentrations before and after dexamethasone. Psychiatry Res 7: 87-92.

Kathol RG (1985) Etiologic implications of corticosteroid changes in affective disorder. Psychiat Med 3: $135-162$.

Kathol RG, Meller W, Jaeckle RS, Lopez JF (1987) Stable adrenocorticotropin-stimulated 11-hydroxylase activity but loss of age-related changes in patients with hypercortisolemia. Biol Psychiatry 22: 1243-1252.

Kathol RG, Anton R, Noyes R, Gehris T (1989) Direct comparison of urinary free cortisol excretion in patients with depression and panic disorder. Biol Psychiatry 25: 873-878.

Kramer RE, Simpson ER, Waterman MR (1983a) Induction of 11-hydroxylase by corticotropin in primary cultures of bovine adrenocortical cells. J Biol Chem 258: 3000-3005.

Kramer RE, McCarthy JL, Simpson ER, Waterman MR (1983b) Effects of ACTH on steroidogenesis in bovine adrenocortical cells in primary culture-increased secretion of 17-hydroxylated steroids associated with a refractoriness in total steroid output. J Steroid Biochem 18: 715-723.

Krause RP, Hux M, Grof P (1987) Psychotropic drug withdrawal and the dexamethasone suppression test. Am $J$ Psychiatry 144: 82-85.

Lejeune-Lenain C, Khodjasteh Z, Copinschi G, Desir D, Franckson JRM (1980) Control of 11- $\beta$-hydroxyandrostenedione secretion in normal adults. In: Genazzani AR, Thijssen JHH, Siiteri PK (Eds) Adrenal Androgens. Raven Press, New York, pp 183-187.

Lewis DA, Pfohl B, Schlechte J, Coryell W (1984) Influence of age on the cortisol response to dexamethasone. Psychiatry Res 13: 213-220.

Liddle GW, Island D, Meador CK (1962) Normal and abnormal regulation of corticotropin secretion in man. Rec Progr Horm Res 18: 125-153.

Maes M, Jacobs M-P, Suy E, Minner B, Raus J (1990) Prediction of the DST results in depressives by means of urinary-free cortisol excretion, dexamethasone levels, and age. Biol Psychiatry 28: 349-357.

McCarthy J, Kramer RE, Funkenstein B, Simpson ER, Waterman MR (1983) Induction of $17 \alpha$-hydroxylase (cytochrome $\mathrm{P}-450_{17 \alpha}$ ) activity by adrenocorticotropin in bovine adrenocortical cells maintained in monolayer culture. Arch Biochem Biophys 222: 590-598.

McEwen BS, De Kloet ER, Rostene W (1986) Adrenal steroid receptors and actions in the nervous system. Physiol Rev 66: 1121-1188.

McEwen BS, Brinton RE, Sapolsky RM (1988) Glucocorticoid receptors and behavior: implications for the stress response. Adv Exp Med Biol 245: 35-45.

Nakajin S, Hall PF (1981) Microsomal cytochrome P-450 from neonatal pig testis. J Biol Chem 256: 3871-3876. 
Nakajin S, Shively JE, Yuan P-M, Hall PF (1981) Microsomal cytochrome P-450 from neonatal pig testis: two enzymatic activities $\left(17 \alpha\right.$-hydroxylase and $\mathrm{C}_{17,20^{-1}}$ yase) associated with one protein. Biochemistry 20: $4037-4042$.

Nelson WH, Orr WW Jr, Shane SR, Stevenson JM (1984) Hypothalamic-pituitary-adrenal axis activity and age in major depression. J Clin Psychiatry 45: 120-121.

Oxenkrug GF, Pomara N, McIntyre IM, Branconnier RJ, Stanley M, Gershon S (1983) Aging and cortisol resistance to suppression by dexamethasone: a positive correlation. Psychiatry Res 10: 125-130.

Perry PJ, Yates WR, Andersen KH (1989) Psychiatric symptoms associated with anabolic steroids: a controlled, retrospective study. Ann Clin Psychiatry 2: 11-17.

Peterson RE, Pierce CE (1960) The metabolism of corticosterone in man. J Clin Invest 39: 741-757.

Pfohl B, Sherman B, Schlechte J, Stone R (1985a) Pituitary-adrenal axis thythm disturbances in psychotic depression. Arch Gen Psychiatry 42: 897-903.

Pfohl B, Sherman B, Schlechte J, Winokur G (1985b) Differences in plasma ACTH and cortisol between depressed patients and normal controls. Biol Psychiatry 20: 1055-1072.

Pope HG, Katz DL (1987) Bodybuilders' psychosis [letter]. Lancet i: 863.

Pope HG, Katz DL (1988) Affective and psychotic symptoms associated with anabolic steroid use. Am J Psychiatry 145: 487-490.

Rapp JP (1986) Adrenal steroid biosynthesis and metabolism. In: Mulrow PJ (Ed) The Adrenal Gland. Elsevier, New York, pp 65-83.

Reus VI, Joseph MS, Dallman MF (1982) ACTH levels after the dexamethasone suppression test in depression. N Engi J Med 306: 283-284.

Reus VI, Joseph MS, Dallman MF (1983) Regulation of ACTH and cortisol in depression. Peptides 4: 785-788.

Rivarola MA, Saez JM, Meyer WJ, Jenkins ME, Migeon CJ (1966) Metabolic clearance rate and blood production rate of testosterone and androst-4-ene-3,17-dione under basal conditions, ACTH and HCG stimulation. Comparison of urinary production rate of testosterone. J Clin Endocrinol Metab 26: 1208-1218.

Robins L, Helzer J, Croughan J, Ratcliff K (1981) National Institute of Mental Health Diagnostic Interview Schedule: its history, characteristics, and validity. Arch Gen Psychiatry 38: 381-389.

Sapolsky RM (1985) A mechanism for glucocorticoid toxicity in the hippocampus: increased neuronal vulnerability to metabolic insults. J Neurosci 5: $1228-1232$.

Satterthwaite FW (1946) An approximate distribution of estimates of variance components. Biometr Bull 2: $110-114$.

Sclare AB, Grant JK (1972) The synacthen test in depressive illness. Scot Med J 17: 7-8.

Sharma RP, Pandey GN, Janicak PG, Peterson J, Comaty JE, Davis JM (1988) The effect of diagnosis and age on the DST: a metaanalytic approach. Biol Psychiatry 24: 555-568.

Simpson ER, Waterman MR (1983) Regulation by ACTH of steroid hormone biosynthesis in the adrenal cortex. Can J Biochem Cell Biol 61: 692-707.

Stokes P (1987) The neuroendocrine measurement of depression. In: Marsella AJ, Hirschfeld RMA, Katz MM (Eds) The Measurement of Depression. Guilford Press, New York, pp 153-195.

Strott CA, Yoshimi T, Lipsett MB (1969) Plasma progesterone and 17-hydroxyprogesterone in normal men and children with congenital hyperplasia. J Clin Invest 48: 930-939.

Tourigny-Rivard M-F, Raskind M, Rivard D (1981) The dexamethasone suppression test in an elderly population. Biol Psychiatry 16: 1177-1184.

von Bardeleben U, Holsboer F (1989) Cortisol response to a combined dexamethasone-human corticotrophinreleasing hormone challenge in patients with depression. $J$ Neuroendocrinol 1: 485-488.

Vaitukaitis JL, Dale SL, Melby JC (1969) Role of ACTH in the secretion of free dehydroepiandrosterone and its sulfate ester in man. J Clin Endocrinol Metab 29: 1443-1447.

Whiteford HA, Peabody CA, Thiemann S, Kraemer HC, Csernansky JG, Berger PA (1987) The effect of age on baseline and post-dexamethasone cortisol levels in major depressive disorder. Biol Psychiatry 22: $1029-1032$.

Zuber MX, Simpson ER, Hall PF, Waterman MR (1985) Effects of adrenocorticotropin on 17 $\alpha$-hydroxylase activity and cytochrome $\mathrm{P}-450_{17 \alpha}$ synthesis in bovine adrenocortical cells. J Biol Chem 260: 1842-1848. 